\title{
Regulation of Criminal Provisions in Administrative Legislation
}

\author{
Jelli Rita ${ }^{1}$, Zudan Arif Fakrulloh ${ }^{2}$ \\ \{jellirita@gmail.com ${ }^{1}$, cclsis@yahoo.com² \\ Universitas Borobudur, Jakarta, Indonesia ${ }^{1,2}$
}

\begin{abstract}
This article analyzes the regulation of criminal provisions in Law Number 19 of 2016 concerning Amendments to Law Number 11 of 2008 concerning Information and Electronic Transactions must still be completed by taking into account various developments in principles and principles that are currently taking place and are being formulated in the Draft Criminal Code, including in this case starting from attention is paid to the principle of material legality which places various legal provisions that apply and grows in the community, while taking into account several mala prohibita issues or criminal acts that arise from statutory provisions and mala inse or criminal acts that arise in connection with demands that develop from public.
\end{abstract}

Keywords: Criminal Provisions; Law; Regulation; Lagislation

\section{Introduction}

Century of 4.0 which was marked by advances in the field of information technology became a part of the life of the nation and the state which cannot be avoided by the existence of Indonesia in the midst of social life in the world. At this time, humans can never be separated from technology. In other words, there is almost no dimension of human life that does not require technological support. This is even more so in the midst of the Covid-19 pandemic health emergency which has forced physical and social distancing, encouraging humans to interact in cyberspace through online media or online (in the network) [1].

At such times, the law will always be a few steps behind the progress of human life that is happening, this is in accordance with the saying that the law is always hobbled to follow human development or which in Dutch is known as: "het recht hink achter de feiten aan". The need to regulate procedures for the new normal forces the law to adapt to the current conditions. Law Number 11 of 2008 concerning Information and Electronic Transactions [2]. As one of the administrative laws that is motivated by the Indonesian nation's efforts to regulate life through or in cyberspace, is one response in the form of legal regulations addressing the ongoing developments. However, it turns out that it still needs improvement after facing 4 [four] judicial reviews through the Constitutional Court of the Republic of Indonesia, each of which decisions consist of Number: 50/PUU-VI/2008 , Number: 2/PUUVII/2009, Number : 5/PUU-VIII/2010 and Number : 20/PUU-XIV/2016.

As a law, the ITE Law is still relatively new, but about 5 (five) years later it has undergone changes through Law Number 19 of 2016 concerning Amendments to Law Number 11 of 
2008 concerning Information and Electronic Transactions. Although changes have been made, in practice there are still perceived problems related to law enforcement. President Joko Widodo's call for changes to the ITE Law has attracted public attention and prompted Machfud MD, as the Coordinating Minister for Political, Legal and Security Affairs (Menko Polhukam) to conduct a study to see if the ITE Law still needs changes [3]. The results of the study were then submitted, that the government ensured that it would revise in a limited way the Law on Information and Electronic Transactions (UU ITE). The revision was carried out to eliminate multiple interpretations that often lead to criminalization efforts in the community, especially related to 4 (four) old articles namely Articles 27, 28, 29 and 36. Meanwhile, there are additional new articles to be formulated, namely Article 45C, which basically contains provisions that regulates criminal matters for people who intentionally disseminate false information or notifications that cause trouble in the community the public and secondly, as well as criminal penalties for anyone who knowingly disseminates electronic information containing uncertain or excessive or incomplete notifications.

Discussions on policy contain various scientific dimensions, because if policy is associated with the preparation of legislation, apart from relating to the discipline of legislation, it will also be in contact with the dimensions of political science (law). Likewise, if it is related to the substance of the Act itself, it will certainly be related to other disciplines. This is generally in line with the theoretical framework of Mahfud MD in his book "Legal Politics in Indonesia" which concludes that law is a political product. Meanwhile, Sudarto argues that implementing criminal law politics means holding elections to find the best results of criminal legislation in the sense of fulfilling the requirements of justice and efficiency. After questioning his actions, at the next stage he will also arrange and place criminal sanctions in the provisions of the legislation, which indubitably also have problems in it. This is in line with Dwija Priyatno's thoughts when examining corporate crimes and stating that there are weaknesses in the absence of special provisions in the preparation of criminal sanctions against corporate crimes which are only sentenced to imprisonment and there is also no substitute criminal provision if the fine has not been paid [4] .

In line with this view, it can be temporarily believed that discussing criminal policy should be a comprehensive work by paying attention to various aspects outside the law, especially in placing criminal provisions in administrative legislation. Therefore, the regulation of criminal provisions is an important and strategic stage in efforts to enforce criminal law. This step is part of the criminal law policy or penal policy, which Barda Nawawi Arief says is the determination of what actions should be made into criminal acts and what sanctions should be imposed on the perpetrators [5]. The preparation of laws and regulations is basically a part of the sub-system of National Development, so it is appropriate that criminal policies also refer to the concept or design of development in a comprehensive and holistic manner.

The various problems mentioned above cannot be separated from the ITE Law, which the President feels still needs to be changed another time, even though it has undergone a change in the first amendment. This is as a result of public complaints questioning the implementation of the ITE Law which is considered a tool to silence public criticism or reduce freedom of expression. In addition to the implementation that still contains problems, the ITE Law is also considered to contain a conflict of norms with the Criminal Code or other existing criminal provisions. So overall, it is these problems that are interesting to do scientific research again in order to obtain a solution to a form of policy using criminal law and obtain a good law which is interpreted by Sudarto as fulfilling the requirements of justice and being efficient. Based on the considerations above, the researchers conducted research on the ITE Law with the title: "Regulation of Criminal Provisions in Administrative Laws (a critical study of Law Number 
11 of 2008 concerning Information and Electronic Transactions as amended by Law No. 11 of 2008 concerning Electronic Information and Transactions). Number 19 of 2016 concerning Amendments to Law Number 11 of 2008 concerning Information and Electronic Transactions".

\section{Methodology}

This study uses a normative legal research method, which is a scientific research procedure to find the truth based on the logic of legal scholarship from the normative side [6]. So that legal research is carried out to produce arguments, theories or new concepts as prescriptions in solving problems at hand. Legal science as a normative science directs its reflection to basic norms that are given a concrete form in the norms specified in certain fields, so that it shows law has prescriptive and applied characteristics, namely legal science applying standard procedures, provisions, signs in implementing the rule of law which means that the science of law is a science that can be applied and is indeed applied by paying attention to the ways in which it is applied [7].

\section{Results and Discussion}

The notion of administration is very broad, covering all the lives of the people of the nation and state. Therefore, it is not easy to provide a definition of administration, but in general it is divided into 2 (two) namely narrow understanding and broad understanding. Administration narrowly only covers the areas of administration, office management and others. Meanwhile, the broad definition of administration is management of an organization which covers a larger field, namely the whole of human life. Similar to the definition of administration, the definition of Administrative Law covers a very broad scope, not only in the fields of tax law, banking, capital markets, and consumer protection but also in the fields of economy, environment, health, education, social welfare, governance space and so on.

This is in line with the understanding of administrative law according to Black's Law Dictionary, which is a set of laws created by administrative institutions in the form of laws, regulations, orders, and decisions to exercise power and regulatory tasks from the institution concerned (body of law created by administrative agencies in the form of rules, regulations, orders, and decisions to carry out regulatory powers and duties of such agencies). Administrative law basically has a specificity in terms of sanctions, namely that it can be imposed by the government without having to wait for a judge's decision, even though administrative sanctions are also the same as criminal sanctions, namely being punitive or burdening violators of administrative provisions in the form of sanctions in the form of suffering [8].

Remmelink also conveyed the specificity of the sanctions from administrative law, who also said that there was no need to use judges and public prosecutors even though they could be imposed and enforced. Meanwhile, when administrative law is associated with criminal law and becomes a phrase of administrative criminal law, according to Barda Nawawi, it has a definition as criminal law in the field of administrative violations that uses criminal law as a means of enforcing administrative law. But in general in the merger of the two legal disciplines In a statutory product, of course, various important principles that apply to the legal discipline must be fulfilled. The merging of these two legal disciplines, of course, when 
packaged in a statutory regulation, requires the involvement of other disciplines related to the procedures for the formation of statutory regulations. Not to mention those related to linguistic disciplines and others. Montesquieu as quoted by Sudarto has put forward the principles of style in the formation of laws [5], namely :

a. His style of language is short and simple: grandiose sentences are simply confusing;

b. The terms used, as far as possible, must be absolute and not relative, so as to give little possibility for different views;

c. The law should limit itself to the real and avoid allusions and hypotheses;

d. The law should not be complicated, because it is intended for people with ordinary grasping power, it must be understood by people in general;

e. He must not obscure the main issue with exceptions, limitations, or changes, unless it is absolutely necessary;

f. He should not give too many excuses; it is dangerous to give lengthy reasons for legislation, for this only opens the door to contention;

g. The most important thing is that it should be carefully considered and have practical uses, and it should not shake reason and justice and "la nature des choses" (what is right); because weak, useless and unfair laws will damage the entire legal system and weaken the authority of the State.

Based on Montesquiou's view above, the legislators should guide it better, namely in every preparation of legislation based on the principles mentioned above. The preparation of administrative law legislation that regulates criminal provisions is generally limited by the principles and principles that apply in the Criminal Code starting from Articles 1 to 103 in Book One in the General Provisions Chapter. As stated above, the issue of norms governing the preparation of laws and regulations as regulated in Law Number 12 of 2011 concerning the Establishment of Legislations is also an important matter that must be guided in the preparation of laws and regulations both theoretically and theoretically. science and technology of manufacture.

The regulation of criminal provisions cannot be separated from the provisions of the preparation of laws and regulations from a systematic perspective. Law Number 12 of 2011 concerning the Establishment of Legislation regulates the systematics starting from the title, a weighing dictum containing historical, juridical and sociological background, a body consisting of general provisions, principles and so on up to one of these bodies. is a subchapter on criminal provisions. Provisions for the formation of laws and regulations are arranged systematically which include; the principle of the formation of laws, that the laws and regulations must be carried out based on the principles of the formation of good laws and regulations. Based on the above discussion, it can be seen that although the ITE Law has been amended and adjusted by taking into account and considering the various results of judicial review of the law through various decisions of the Constitutional Court, in In fact, it has not been able to solve the main problems that are currently the attention of the community and the state. These various problems include :

a. There is still a normalization conflict between the general norms regulated in the Criminal Code and the norms regulated in the ITE Law. For example, the norms regarding defamation acts regulated in the general provisions of the Criminal Code are not specifically deviated or indeed fully followed in principles and principles. Although there has been a decision from the Constitutional Court, changes specifically that translate it clearly in the norm have not been made. Efforts to normalize clearly can actually be followed by a pattern of normalization as regulated in the Criminal Procedure Code, as a criminal law that regulates criminal provisions and is referred to as a special crime but can 
place the Criminal Code as a sui generis properly because of the provisions of Article 1 and Article 2 of the Criminal Procedure Code as a good interconnection. contained in Article 103 of the general provisions of the Criminal Code.

b. There is still uncertainty related to the procedural law of criminal provisions specifically regulated in the ITE Law, namely the treatment of evidence or evidence obtained from electronics that are not yet known in the Criminal Procedure Code, especially Article 184 of the Criminal Procedure Code which has not placed electronic evidence such as transcripts of conversations. by telephone, telegram, print out of what apps messages, pictures and or recordings and others. In fact, through the decision of the Constitutional Court, it has been explained that all evidence obtained from electronic means is legally valid evidence. Therefore, it is necessary to conduct a special norm regarding this matter.

c. Synchronization and harmonization with various provisions related to actions. What is prohibited in the ITE Law needs to be reworked more thoroughly and accurately so that all provisions related to normalizing with other laws do not cause problems in their application. For example, the provisions relating to consumer protection that may be in commerce through online media which have recently shown a very sharp increase in transaction rates.

d. It is necessary to affirm the expansion of the subject of criminal acts in the form of corporations and how are the sanctions and accountability so that the ITE Law will be equipped with provisions relating to the subject of criminal acts.

e. Requires an omission offense setting that requires computer users or Internet users or networks or activities in cyberspace have an obligation or obligation as a standard of behavior in activities in cyberspace. Thus, good legislation is legislation that Sudarto says has benefits for the community and is effective, while citing Montesquieu's opinion has practical uses, and it should not shake common sense and justice and "la nature des choses" (what is proper). ); because weak, useless and unfair laws will damage the entire legal system and weaken the authority of the State.

\section{Conclusion}

Through this brief research, the following conclusions can be drawn : (a) Regulation of criminal provisions in administrative legislation is generally carried out by taking into account the various principles that are mandatory to follow, such as the provisions stipulated in Law Number 12 of 2011 concerning the Establishment of Legislation and the principles that apply in criminal law and administrative law. As befits the use of criminal law policies in administrative legislation, every regulation of criminal provisions should not reduce criminal law and vice versa. (b) Arrangement of criminal provisions regulated in Law Number 19 of 2016 concerning Amendments to Law Number 11 of 2008 concerning Information and Electronic Transactions is expected to be able to avoid various problems in making legislation such as conflicts in norming, duplication of regulations, weak harmonization and synchronization processes as well as the possibility of implementing various developments in principles or principles in criminal law as well as in administrative law. The regulation of criminal provisions in this case should begin to follow the progress or development of the principles being formulated in the Draft Criminal Code such as the principle of material legality, alternative criminal sanctions applied, including the issue of applying various theories such as judge pardons or rechtelijk pardon, restorative justice and others. 


\section{References}

[1] H. Parish, "The absence of presence and the presence of absence: social distancing, sacraments, and the virtual religious community during the covid-19 pandemic," Religions, 2020, doi: 10.3390/rel11060276.

[2] Sekretariat Negara, "Republic of Indonesia, Law Number: 11 of 2008 concerning Information and Electronic Transactions." Jakarta, 2008.

[3] M. M.D, Legal Politics in Indonesia, Second. Jakarta: PT. LP3ES Library, 2009.

[4] D. Priyatno, Legislative Policy on the Coorporate Liability System in Indonesia. Bandung: CV. Utomo, 2004.

[5] B. N. Arief, Head of Criminal Law Selection. Bandung: PT. Image of Aditya Bakti, 2003.

[6] D. L. Sonata, "METODE PENELITIAN HUKUM NORMATIF DAN EMPIRIS: KARAKTERISTIK KHAS DARI METODE MENELITI HUKUM," FIAT JUSTISIAJurnal Ilmu Huk., 2015, doi: 10.25041/fiatjustisia.v8no1.283.

[7] I. M. P. Diantha, "Metodologi Penelitian Hukum Normatif," Teor. Metodol. Penelit. a., 2017.

[8] Philipus M. Hadjon et al, Introduction to Indonesian Administrative Law. Yogyakarta: Gajahmada University Pressy, 2003. 